\title{
En litterær åreknute
}

\author{
Aleksandr Sergejevitsj Pusjkin (1799-1837) er en av Russlands mest kjente diktere. Han dramatiserte sine \\ åreknuter for å vekke medlidenhet hos slekt, venner og myndigheter. Det var imidlertid ikke åreknutene som \\ til slutt skulle forvolde hans død.
}

\section{Per Joachim Lund}

perjoachim@gmail.com

Oslo

Pusjkin tilhørte på farssiden en av Russlands eldste adelsfamilier. Herkomsten på morssiden er mer broket: Oldefaren var en frikjøpt slave fra Kamerun som ble forært til tsar Peter den store (1672-1725), og senere ble tsarens protesjé. Pusjkins oldemor, Christina Regina Siöberg (1705-81), hadde via Baltikum og Skåne aner i Galtung-slekten fra herregården Torsnes i Hardanger $(1,2)$. Pusjkins foreldre var selvskrevne medlemmer av sosieteten i St. Petersburg og var mer opptatt av det sosiale liv der enn av hjemlige sysler. De fikk åtte barn, men bare tre av dem nådde voksen alder.

\section{Sensurert og forvist til provinsen} Pusjkin publiserte sitt første dikt 15 år gammel og ble snart anerkjent i de russiske litterære kretser. Etter fullført gymnasium ble han ansatt i Utenriksdepartementet. Ansettelsen var bare nominell, og han hadde ingen arbeidsoppgaver. Etter napoleonskrigene var makthaverne i Europa engstelige for revolusjonære bevegelser, slik også i Russland. Det ble opprettet et hemmelig politi og innført streng sensur av all litteratur. Noen av Pusjkins dikt var obskøne, blasfemiske og regimekritiske. De vakte derfor myndighetenes mishag. Pusjkin ble mistenkt for å ha forbindelser med opposisjonelle grupper og ble beordret til å forlate St. Petersburg. Som offentlig tjenestemann fikk han beskjed om å reise til et fjerntliggende landdistrikt for å delta $\mathrm{i}$ bekjempelsen av gresshopper som hadde invadert svartehavskysten. Den urbane Pusjkin ble fortvilet og skrev et langt brev til stabssjefen der han ba om å bli fritatt. Han sluttet brevet slik: «... De vet kanskje ikke at jeg har et aneurisme. De siste åtte årene har jeg båret døden med meg. Jeg kan skaffe en attest fra hvilken som helst lege De ønsker. Er det ikke mulig å la meg være i fred resten av mitt liv, som sikkert ikke vil bli langt?» (alle sitater er oversatt fra (2)

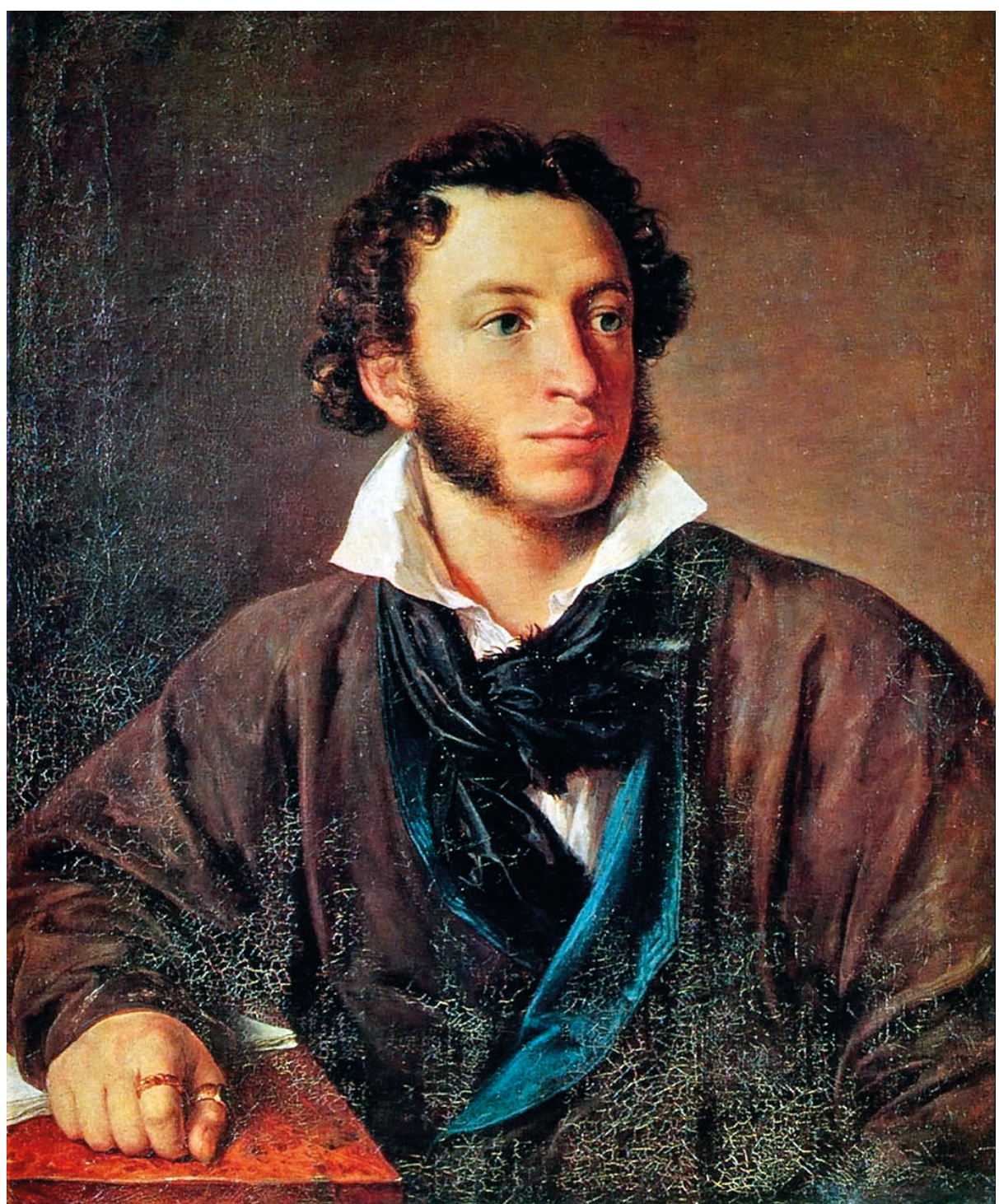

Aleksandr Sergejevitsj Pusjkin (1799-1837), 1827, Vasilij Andrejevitsj Tropinin. Wikipedia Commons

av forfatteren). Dette hjalp ikke; han måtte likevel delta i gresshoppekrigen.

Pusjkin kom stadig i konflikt med myndighetene og ble i 1824 beordret til å bosette seg på morens landeiendom i nærheten av den lille byen Pskov, sør for St. Petersburg. Han syntes denne forvisningen hindret hans livsutfoldelse og lammet hans dikteriske evner. Han klekket ut en fluktplan. Han ville få sin dikter- kollega, Vasilij Andrejevitsj Zjukovskij (1783-1852), til å overtale en slektning, professor Ivan Filippovitsj Moyer (1786-1858) ved universitetet i Dorpat (nå Tartu) i Estland, til å motta Pusjkin for operasjon (2). Fra Dorpat ville det være lett å flykte til utlandet. Enda bedre ville det være å få Moyer til å erklære at tilstanden var så livstruende at den bare kunne behandles i f.eks. Paris. 


\section{Spiller på dårlig helse}

Pusjkins bror, Lev Sergejevitsj Pusjkin

(1805-52) satte ballen i gang ved å spre rykter om Pusjkins blodårer. Dette fikk Zjukovskij til å sende et engstelig brev der han skrev: «...Er det sant at du har et aneurisme i leggen, og at du har hatt denne gjesten i ti år uten å fortelle det til noen?» Pusjkin svarte straks og blåste kjekt av at han var dømt til en tidlig grav: «Jeg har hatt mitt aneurisme i ti år, og med Guds hjelp kan jeg nok tåle det enda noen år. Så det har ingen hast, men livet her er kvelende for meg.» Han la ved en søknad som skulle leveres til tsar Aleksander I (1777-1825), om tillatelse til å reise til utlandet for å opereres for aneurismet.

Men da søknaden nådde St. Petersburg, syntes Pusjkins venner at den ikke var ydmyk nok, så de erstattet den med et brev fra Pusjkins mor: «Det er med all bekymring $\mathrm{i}$ en mors ømme hjerte at jeg ved Deres Keiserlige Majestets føtter våger å bønnfalle om en velgjerning for min sønn! ... Min sønn har lidd i mer enn ti år av et aneurisme i leggen; min sønn som stort sett har forsømt denne sykdommen, finner nå hvert øyeblikk sine dager truet av den, først og fremst fordi han befinner seg i Pskovprovinsen som mangler alle hjelpemidler. Vær nådig, og tillat min sønn å reise til Riga eller en annen by som Deres Majestet måtte utpeke, for å gjennomgå en operasjon som er det eneste som kan gi meg håp om å få beholde ham ...»

Det kom svar fra generalstabssjefen som hadde ansvar for slik korrespondanse: «Hans Majestet som har gjort seg kjent med brevet som var sendt ham 6 . mai, har bedt meg, Madame, om å informere Dem om at Hans Majestet tillater Deres sønn å reise til behandling i Pskov, der han kan finne all nødvendig hjelp uten å behøve å reise til Riga.» Samtidig ble guvernøren bedt om å holde øye med Pusjkins oppførsel.

\section{Avslørt?}

Da Pusjkin fikk beskjed om dette svaret, ble han rasende. Det var ikke noe håp om å flykte til Europa fra Pskov. Han sendte et sarkastisk brev til Zjukovskij: «Hans Majestets uventete gunstbevisning har rørt meg ubeskrivelig, særlig fordi guvernøren her allerede hadde tilbudt meg å bo i Pskov. ... Jeg har forhørt meg om kirurgene i Pskov. Der ble jeg henvist til en viss Vsevolozjskij, en meget dyktig veterinær, kjent i fagmiljøet for sin bok om behandling av hester. Ikke desto mindre har jeg besluttet å forbli her i Mikhailovskoje, selv om jeg er klar over Hans Majestets faderlige velvilje.»
Etter hvert ble den forutsigbare selvmotsigelsen i Pusjkins plan åpenbar. Han ønsket ingen operasjon, som ville avsløre at hans lidelse slett ikke var livstruende. Men han hadde lyktes altfor godt å overbevise sine venner om at døden var nær forestående. Fulle av bekymring bønnfalt de ham om å legge seg under kniven. Zjukovskij skrev til professor Moyer og ba ham reise til Pskov for å utføre operasjonen. Da Pusjkin hørte dette, skrev han et desperat brev til Moyer: «For Guds skyld, kom ikke! Bekymre Dem ikke om meg. Operasjonen for aneurismet er for uviktig til å ta en berømt mann bort fra hans gjøremål og

«Vær nådig, Deres Majestet, tillat min sønn å reise til et annet sted, der han kan finne en mer erfaren kirurg, og unnskyld en mor som skjelver for sin sønns liv, for at hun enda en gang bønnfaller om Deres barmhjertighet»

hans hjem. Deres gode gjerning ville smerte min samvittighet.» Pusjkin hadde da fått vite at Moyer var kjent for sin ærlighet og integritet og neppe ville la seg bestikke.

Så følger en lang korrespondanse der vennene trygler ham om å la seg operere, mens Pusjkin, urettferdig nok, irritert ber dem om ikke å blande seg i hans saker. Han bestemte seg for å skrive direkte til tsaren: «... Min helse fikk en knekk i min ungdom - et aneurisme i hjertet krever øyeblikkelig operasjon eller langvarig behandling. Et opphold i Pskov, den byen jeg har fătt tildelt, vil ikke hjelpe meg. Jeg bønnfaller Deres Majestet om å tillate meg å få bo $i$ en av våre hovedsteder eller foreslå en by i Europa hvor jeg kan ta vare på min helse.» Hvordan aneurismet hadde forflyttet seg fra leggen til hjertet fikk ingen forklaring.

Ved nærmere ettertanke unnlot han å sende brevet.

\section{Siste forsøk}

Etter et par uker skrev han til Zjukovskij og fortalte at han hadde vært i Pskov og oppsøkt en lege som hadde sagt at operasjon ikke var nødvendig, men at det i så fall var nødvendig med strenge forholdsregler. Pusjkins mor skrev enda et bønnfallende brev til tsaren uten å få svar: «Vær nådig, Deres Majestet, tillat min sønn å reise til et annet sted, der han kan finne en mer erfaren kirurg, og unnskyld en mor som skjelver for sin sønns liv, for at hun enda en gang bønnfaller om Deres barmhjertighet.»

Et halvt år senere fikk generalguvenøren for Baltikum en attest fra helsemyndighetene i Pskov der det fremgikk at Pusjkin hadde «på underekstremitetene, og spesielt på høyre legg, en generell utvidelse av venen (varicositas totius cruri dextri), som hemmer ham i å gå». Attesten ble sendt til tsar Nikolai I (1796-1855) sammen med brev fra Pusjkin der han henviser til attesten og igjen ber om tillatelse til å reise til Moskva, St. Petersburg eller utlandet. Han fikk ingen slik tillatelse.

Tatt til nåde, men spiller med sitt liv Etter et langt møte med tsaren i 1826 ble Pusjkins indre eksil opphevet, og etter dette foreligger ingen opplysninger om hans åreknuter. Han reiste til St. Petersburg, giftet seg og deltok iherdig i byens selskapsliv. Han var ømskinnet når det gjaldt sin ære og var innblandet i 29 dueller. I 1837 duellerte han med sin svoger, Georges d'Anthès, som hadde forsøkt å forføre hans hustru. Pusjkin ble livstruende såret og døde et par dager etter, antakelig med sine varicer intakt.

\section{Per Joachim Lund (f. 1928)}

er pensjonert kommunelege. Han er spesialist i allmennmedisin og i samfunnsmedisin og har tatt eksamen i russisk mellomfag og i idéhistorie grunnfag.

Forfatter har fylt ut ICMJE-skjemaet og oppgir ingen interessekonflikter

\section{Litteratur}

1. Lihaug EG. Grabow, Galtung - og Pusjkin. Søkelys på en europeisk sammenheng. Norsk slektshistorisk tidsskrift 2003: Bind XXXIX - hefte 1:93-133.

2. Binyon TJ. Pushkin. A biography. New York: Alfred A. Knopf, 2003

Mottatt 9.1. 2012, første revisjon innsendt 2.2. 2012, godkjent 16.2. 2012. Medisinsk redaktør Are Brean. 